\title{
MENINGKATKAN KEMAMPUAN METAKOGNITIF DAN AKTIVITAS BELAJAR MELALUI PENERAPAN MODEL PEMBELAJARAN TALKING STICK DI SMPN 1 BALEREJO TAHUN PELAJARAN 2014/2015
}

\author{
Mia Zhendy Agustina ${ }^{1)}$, Marheny Lukitasari ${ }^{2)}$ \\ Program Studi Pendidikan Biologi FPMIPA IKIP PGRI MADIUN \\ email: mzhenndy@ymail.com
}

Diterima 26 Juli, Disetujui 27 September 2015

\begin{abstract}
The study aims to determine the improvement of metacognitive skills and learning activities of students through a learning model talking stick. Classroom action research is done in SMPN 1 Balerejo. Data collection techniques metacognitive skills and learning activities using observation sheet. Results of the first cycle study metacognitive skills 44,22. Results of the first cycle of study learning activities 40,3. Results of the second cycle study metacognitive skills 84,74. Results of second cycle studies 82,62. Conclusion there is an increase in metacognitive skills and learning activities of students through the application of learning models talking stick on the subject matter density of population on the environment SMPN1 Balerejo academic year 2014/2015 .
\end{abstract}

Keywords : metacognitive skills, learning activities, talking stick

\section{PENDAHULUAN}

Salah satu pelajaran yang siswa sulit untuk memecahkan adalah pelajaran IPA. Pada pelajaran IPA siswa kurang tertarik karena kecenderungannya menghafal, sehingga siswa cepat lupa apa yang telah dipelajarinya. Agar siswa dapat belajar dan memahami pelajaran dengan baik, terlebih dahulu mereka harus mengetahui cara belajar yang sesuai dengan karakter. Sehingga dapat belajar dengan benar dan memahami pelajaran sesuai dengan gaya belajar mereka (Ma'rifah, 2013).

Bahri dan Apriana (dalam Mumpuni, 2012) menyatakan bahwa kemampuan metakognisi mempunyai indikator ketika siswa mampu berpikir dengan mengoptimalkan kemampuan berpikir yang dimiliki, mengidentifikasi strategi belajar yang baik dan secara sadar mengarahkan strategi belajarnya. Strategi belajar berkaitan dengan aktivitas belajar siswa, dan biasanya berbeda-beda sesuai dengan karakternya.

Hasil penelitian Putri (2010) melalui penggunaan model talking stick menunjukkan adanya peningkatkan hasil belajar siswa. Karena siswa tidak bosan dan senang dengan kegiatan belajar tersebut.
Tujuan penelitian yang ingin dicapai adalah 1) meningkatkan kemampuan metakognitif siswa menggunakan model pembelajaran talking stick pada materi pelajaran kepadatan populasi terhadap lingkungan di SMP Negeri 1 Balerejo tahun pelajaran $2014 / 2015$. 2) meningkatkan aktivitas belajar siswa menggunakan model pembelajaran talking stick pada materi pelajaran kepadatan populasi terhadap lingkungan di SMP Negeri 1 Balerejo tahun pelajaran 2014/2015.

\section{METODE \\ Pendekatan dan Jenis Penelitian}

Jenis penelitian ini adalah Penelitian Tindakan Kelas (PTK), yaitu suatu rancangan penelitian yang dirancang khusus untuk meningkatkan kualitas praktek pembelajaran di kelas.

\section{Subjek Penelitian}

Subjek penelitian adalah siswa SMP Negeri 1 Balerejo tahun pelajaran 2014/2015, berjumlah 30 siswa. 


\section{Teknik Pengumpulan Data}

Pengumpulan data menggunakan teknik nontes dengan observasi dan wawancara yang masing-masing secara singkat diuraikan sebagai berikut.

\section{Kemampuan metakognitif}

Data tentang kemampuan metakognitif siswa diambil dengan cara memberikan lembar observasi pada guru kelas, yaitu menggunakan lembar observasi kemampuan metakognitif. Observasi dilakukan secara langsung berdasarkan pengamatan, dilakukan pada saat siswa melakukan diskusi materi selama 4 kali pertemuan pada KD 4 setelah diterapkan model pembelajaran talking stick yang dilakukan pada pertemuan pertama sampai keempat. Adapun komponen lembar observasi menggunakan 5 indikator yaitu, menentukan tujuan pembelajaran; mempelajari materi pelajaran; Bertukar pendapat antar teman, Memberi kesimpulan hasil diskusi

\section{Aktivitas Belajar}

Data aktivitas belajar siswa berupa lembar observasi, menggunakan 10 indikator yaitu: 1) memperhatiakan apa yang disampaikan guru; 2) Bertanya dan menyampaikan pendapat pada saat kegiatan belajar atau diskusi; 3) bekerja sama dengan teman; 4) membuat perencanaan yang akan dikerjakan; 5) Bertanggung jawab terhadap tugas yang telah ditetapkan; 6) Mengerjakan masalah yang dihadapi dalam kegiatan belajar mengajar; 7) Bertukar pendapat antar teman; 8) Memiliki kepedulian terhadap kesulitan sesama teman; 9) Menyimpulkan pembelajaran; 10) Mengerjakan kuis dengan kemampuan sendiri.

\section{Kualitas Pelaksanaan Pembelajaran}

Data kualitas pelaksanaan pembelajaran diperoleh melalui observasi aktivitas guru dan siswa selama proses kegiatan pembelajaran. Instrumen yang dipergunakan adalah rubrik penilaian menggunakan lembar observasi.

\section{Prosedur Penelitian}

Prosedur penelitian tindakan kelas (PTK), terdiri dari 4 kegiatan, yaitu: perencanaan, pelaksanaan, pengamatan dan refleksi. Siklus dalam PTK direncanakan secara sistematis untuk mendapatkan hasil yang sesuai dengan keinginan peneliti. Peningkatan kemampuan metakognitif dan aktivitas belajar siswa melalui penerapan model pembelajaran talking stick Materi pelajaran kepadatan populasi dengan lingkungan di SMP Negeri 1 Balerejo, yang dilaksanakan dalam 2 siklus.

Siklus pada penelitian tindakan kelas dilakukan dengan alur penelitian sebagai berikut.

\section{Siklus I}

a. Perencanaan

Menyediakan perangkat penelitian, meliputi 1) Rencana Kegiatan Harian (RKH) yang mencakup: indikator, kegiatan pembelajaran, alat (tongkat) dan rubrik penilaian kemampuan metakognitif dan aktivitas belajar. 2) Menyiapkan media pembelajaran, yaitu: materi pelajaran dan tongkat.3) Membuat lembar observasi siswa dan lembar hasil belajar siswa

\section{b. Pelaksanaan Tindakan}

Rencana pembelajaran yang telah dirancang pada tahap perencanaan, dilaksanaan sepenuhnya pada tahap pelaksanaan ini. Secara garis besar kegiatannya mencakup hal-hal sebagai berikut:

Pelaksanaan kegiatan pembelajaran dengan menerapkan model talking stick di awali dengan guru menjelaskan alur pembelajaran yang akan dilaksanakan pada kegiatan sebagai berikut:

1) Menyampaikan tujuan pembelajaran.

2) Siswa membaca materi yang diberikan oleh guru dengan waktu yang telah disediakan. 
3) Memberikan tongkat pada siswa, saat bernyanyi bersama. Pada saat lagu berhenti siswa yang memegang tongkat terakhir harus menjawab pertanyaan yang diberikan oleh guru.

4) Kegiatan penutup, meliputi: kegiatan membuat lembar hasil belajar siswa melalui soal formatif, dan doa penutup.

\section{c. Observasi}

Observasi dilakukan dari awal sampai akhir proses pembelajaran, dilakukan oleh guru menggunakan lembar observasi dan dilakukan pada saat pembelajaran berlangsung.

\section{Siklus II}

Siklus kedua dilakukan pula keempat tahapan yang meliputi tahap rancangan, tahap kegiatan dan pengamatan dan tahapan refleksi. Siklus kedua pada tahap pelaksanaan dilakukan semua rencana perbaikan yang telah ditetapkan pada siklus sebelumnya, apabila tujuan dari penelitian belum tercapai, maka harus dilakukan siklus penelitian sampai tujuan penelitian tercapai.

\section{Indikator Kinerja}

Target pencapaian dalam penelitian ini adalah pencapaian indikator pada aspek peningkatan kemampuan metakognitif, aktivitas belajar dan kualitas pelaksanaan pembelajaran biologi siswa sesuai yang diharapkan peneliti. Berikut rincian target yang ingin dicapai peneliti dalam penelitian ini.

Tabel 1. Target Pencapaian

\begin{tabular}{lcc}
\hline \multirow{2}{*}{ Aspek } & \multicolumn{2}{c}{ Nilai Rata-rata Kelas } \\
\cline { 2 - 3 } & Siklus I & Siklus II \\
\hline Kemampuan & 67 & 68 \\
metakognitif & & \\
Aktivitas belajar & 60 & 61 \\
Kualitas & 70 & 80 \\
Pelaksanaan & & \\
Pembelajaran & & \\
\hline
\end{tabular}

\section{Teknik Analisis Data}

Analisis data dalam penelitian ini dilakukan selama dan setelah pengumpulan data.

1. Kemampuan metakognitif dan aktivitas belajar, dianalisa dengan menggunakan rumus:

$$
N=\frac{F}{n} X 100
$$

$\mathrm{N}=$ Nilai

$\mathrm{F}=$ Jumlah skor yang diperoleh siswa

$\mathrm{n}=$ Jumlah skor maksimum

(Sugiyono dalam Wulandari, 2012)

2. Data presentase skor yang diperoleh melalui observasi guru dan siswa selama proses kegiatan pembelajaran diinterprestasikan dalam kriteria keterlaksanaan pembelajaran sebagai berikut.

Tabel 2. Kriteria Keterlaksaan

\begin{tabular}{ll}
\hline Skala & Interpretasi \\
\hline Kurang dari 60 & Tidak Baik \\
\hline $60 \%-69 \%$ & Kurang Baik \\
\hline $70 \%-79 \%$ & Cukup Baik \\
\hline $80 \%-89 \%$ & Baik \\
\hline $90 \%-100 \%$ & Sangat Baik \\
\hline
\end{tabular}

Sumber: Sudjana (2011)

\section{HASIL DAN PEMBAHASAN}

Berdasarkan pengamatan hasil rubrik kemampuan metakognitif siswa selama pelaksanaan pembelajaran siklus I dapat disajikan dalam Tabel 3.

Tabel 3. Hasil Rubrik Kemampuan Metakognitif Siswa Siklus I

\begin{tabular}{lc}
\hline \multicolumn{1}{c}{ Uraian } & Jumlah \\
\hline $\begin{array}{l}\text { Jumlah siswa yang hadir } \\
\text { Jumlah nilai kemampuan }\end{array}$ & 88,44 \\
metakognitif siswa & \\
\hline Nilai rata-rata kelas & 44,22 \\
\hline
\end{tabular}

Nilai rata-rata kelas yang dicapai pada siklus 1 tahap I dan II sebesar 44,22 dan belum mencapai target pencapaian yang 
ditetapkan yaitu sebesar 67. Hasil aktivitas belajar siswa siklus I seperti pada Tabel 4 . Nilai rata-rata kelas yang dicapai pada siklus 1 tahap I dan II sebesar 40,3 dan belum mencapai target pencapaian yang ditetapkan yaitu sebesar 60 .

Tabel 4. Hasil Rubrik Aktivitas Belajar Siswa Siklus I

\begin{tabular}{ll}
\hline \multicolumn{1}{c}{ Uraian } & \multicolumn{1}{c}{ Jumlah } \\
\hline $\begin{array}{l}\text { Jumlah siswa yang hadir } \\
\text { Jumlah nilai aktiviras }\end{array}$ & 29 \\
belajar siswa & 80,6 \\
\hline Nilai rata-rata kelas & 40,3 \\
\hline
\end{tabular}

Kemampuan metakognitif siswa pada siklus I belum mencapai target baik yang ditetapkan peneliti sebesar 68. Hasil siklus I disebabkan masih rendahnya kemampuan dari sisi merencanakan, melaksanakan dan mengevaluasi siswa dalam pembelajaran, guru juga belum menyampaikan tujuan pembelajaran kepada siswa. Upaya yang dilakukan untuk mengatasi kurangnya pencapaian nilai siswa peneliti menyampaikan tujuan pembelajaran yang akan dicapai di awal proses pembelajaran. Serta memberikan dorongan kepada siswa akan pentingnya pelajaran yang disampaikan untuk mencapai suatu tujuan.

Aktivitas belajar siswa pada siklus I belum mencapai target yang ditetapkan yaitu 61, hal ini disebabkan siswa kurang memperhatikan penjelasan guru, siswa kurang bekerjasama dengan teman, kurang bertanggung jawab atas tugas yang telah diberikan, sehingga kesulitan dalam menyimpulkan pelajaran dan kesulitan dalam mengerjakan kuis. Berdasarkan pengamatan hasil rubrik kemampuan metakognitif siswa selama pelaksanaan pembelajaran siklus II dapat disajikan dalam Tabel 5.

Tabel 5.Hasil Rubrik Kemampuan Metakognitif Siswa Siklus II

\begin{tabular}{cl}
\hline Uraian & \multicolumn{1}{c}{ Jumlah } \\
\hline Jumlah siswa yang hadir & 29 \\
& 169,48 \\
\hline
\end{tabular}

\begin{tabular}{ll}
\hline Jumlah nilai kemampuan \\
metakognitif siswa
\end{tabular}

Nilai rata-rata kelas yang dicapai pada siklus II tahap I dan II sebesar 84,74 dan telah mencapai target pencapaian yang ditetapkan peneliti pada tabel 3,4 sebesar 68 . Berdasarkan pengamatan hasil rubrik aktivitas belajar siswa selama pelaksanaan pembelajaran siklus II dapat disajikan dalam Tabel 6. Nilai rata-rata kelas yang dicapai pada siklus II tahap I dan II sebesar 82,625. Nilai ini telah mencapai target pencapaian yang ditetapkan peneliti pada tabel 3,4 sebesar 61.

Tabel 6. Hasil Rubrik Aktivitas Belajar Siswa Siklus II

\begin{tabular}{lc}
\hline \multicolumn{1}{c}{ Uraian } & Jumlah \\
\hline $\begin{array}{l}\text { Jumlah siswa yang hadir } \\
\text { Jumlah nilai aktivitas }\end{array}$ & 165,253 \\
belajar siswa & \\
\hline Nilai rata-rata kelas & 82,625 \\
\hline
\end{tabular}

Kegiatan pembelajaran dengan metode pembelajaran talking stick menunjukkan hasil kemampuan metakognitif dan aktivitas belajar siswa telah mencapai target pencapaian yang ditetapkan. Hasil refleksi pelaksanaan tindakan pada siklus II adalah siswa sudah memperhatikan apa yang disampaikan guru, siswa sudah bisa menentukan tujuan pembelajaran sendiri, siswa sudah aktif dalam pembelajaran, dan nilai rata-rata kelas sudah mengalami peningkatan dari sklus sebelumnya. Data kualitas pembelajaran diperoleh melalui lembar observasib selama proses kegiatan pembelajaran. Adapun data hasil kualitas pembelajaran pada pertemuan 1 dan pertemuan 2 seperti pada Tabel 7 .

Tabel 7. Hasil Observasi Kualitas Pelaksanaan Pembelajaran

\begin{tabular}{lcc}
\hline \multicolumn{1}{c}{ Pelaksanaan } & Siklus 1 & Siklus 2 \\
\hline Pendahuluan & 5,5 & 9 \\
Kegiatan inti & 21,5 & 32 \\
Penutup & 9 & 14
\end{tabular}




\begin{tabular}{lcc}
$\Sigma$ & 27 & 55 \\
Rata-rata & 2,25 & 4,5 \\
$\%$ & 63 & 85 \\
$\mathrm{~N}$ & KB & B \\
Kriteria & Kurang & Baik \\
& Baik & \\
\hline
\end{tabular}

Kegiatan pembelajaran dengan metode pembelajaran talking stick menunjukkan hasil kemampuan metakognitif dan aktivitas belajar siswa telah mencapai target pencapaian yang ditetapkan. Hasil pelaksanaan tindakan pada siklus II adalah siswa sudah memperhatikan apa yang disampaikan oleh guru. Siswa sudah bisa menentukan tujuan pembelajaran, sudah aktif dalam pembelajaran dan kerja sama siswa dalam mengerjakan tugas sudah baik serta nilai rata-rata kelas sudah mengalami peningkatan dari siklus sebelumnya. Berdasarkan hasil siklus I dan siklus II maka penelitian tidak dilanjutkan pada siklus berikutnya.

Penerapan model pembelajaran talking stick yang diimplementasikan di dalam kelas VII memberikan dampak yang positif dalam peningkatan kemampuan metakognitif dan aktivitas belajar siswa. Materi pembelajaran yang diajarkan selama penelitian siklus I dan siklus II yaitu kepadatan populasi terhadap lingkungan. Materi kepadatan populasi terhadap lingkungan mampu membuat siswa aktif karena siswa dapat melakukan langkah yang sistematis dalam mengenal komponenkomponen dalam pengaruh kepadatan populasi manusia terhadap lingkungan berupa penyebab perubahan yang terjadi pada ekosistem, permasalahan yang timbul, akibat dari kepadatan populasi, dan upaya pemerintah dalam mengatasi kepadatan populasi, hal ini terutama terjadi melalui penerapan model pembelajaran talking stick, karena siswa menjadi mengetahui letak kesalahannya sehingga dapat mengerjakan soal sesuai petunjuk yang diberikan guru. Siswa tidak mengulangi kesalahan yang sama saat mengerjakan soal yang serupa.
Siklus I menunjukkan rata-rata kemampuan metakognitif siswa sebesar 44,22\%. Kemampuan metakognitif pada siklus I menunjukkan tingkatan tidak nyata atau tidak mampu memisahkan apa yang dipikirkan dengan bagaimana ia berpikir, hal ini terlihat pada kesulitan siswa dalam menentukan tujuan pembelajaran. Hasil ratarata lembar observasi siswa kemampuan metakognitif siklus I menunjukkan bahwa siswa belum bisa mengkonstruksi hasil belajarnya sendiri terkait dengan apa yang belum diketahui dalam bacaan. Jawaban siswa juga tidak menunjukkan jawaban yang benar dan lengkap. Tahapan perencanaan, banyak siswa yang kesulitan dalam memahami tujuan pembelajaran. Tahapan tindakan, siswa belum terbiasa pada penerapan model pembelajaran talking stick sehingga sulit mempelajari materi pelajaran secara cepat. Tahapan monitoring, siswa tidak bertukar pendapat antar teman, takut jika dimarahi guru karena dapat menimbulkan gaduh dan menurunkan konsentrasi, sehingga siswa memilih untuk belajar sendiri. Tahapan evaluasi, siswa belum terbiasa untuk merefleksi hasil belajarnya.

Ranah kemampuan metakognitif siswa pada siklus II mengalami peningkatan menjadi $84,74 \%$ setelah sebelumnya pada siklus I sebesar $44,22 \%$. Siklus II siswa lebih bisa mengkonstruksi hasil belajarnya sendiri, sehingga siswa lebih bisa mengemukakan apa yang belum siswa mengerti pada materi, siswa lebih bisa menjabarkan dan menyebutkan apa yang belum siswa mengerti dan pahami dalam materi, hal ini menunjukkan bahwa adanya peningkatan dalam pemahaman materi pelajaran.

Kemampuan metakognitif tercermin dalam mempelajari materi pada tahap perencanaan, siswa sudah mulai menentukan tujuan pembelajaran. Tahap tindakan, siswa sudah bersungguh-sungguh dalam mempelajari materi pelajaran. Tahapan monitoring, siswa sudah bisa memonitoring hasil belajarnya sehingga dapat mengetahui 
kekurangan dalam mempelajari materi dan menjawab pertanyaan dari guru. Menurut hasil penelitian Steven (dalam Fitriani, 2013) melalui strategi metakognitif peserta didik didorong untuk mengembangkan rasa pengetahuan mereka sendiri dan mempengaruhi motivasi siswa untuk belajar sehingga siswa dapat menyelesaikan tugas mereka dengan baik. Siswa sudah mulai bertukar pendapat antar teman. Tahapan evaluasi, dari siklus I ke siklus II siswa mulai bisa merefleksi hasil belajarnya. Berdasrkan hasil penelitian Marheny, et al., (2014) menunjukkan bahwa kemampuan metakognitif dapat mempengaruhi pemahaman konsep siswa, jika siswa mampu merefleksi hasil belajarnya dengan baik maka pemahaman konsep siswa dalam belajar sudah mengalami peningkatan.

Veenman, et al., (2004:

Kemampuan metakognitif sangat diperlukan untuk mengerjakan tugas, karena mahasiswa menjadi lebih terampil dan focus, hal tersebut menunjukkan, perencanaan dalam belajar lebih terinci dengan baik. Karena perencanaan memerlukan ketelitian selama mengerjakan tugas. Bekerja secara sistematis sesuai dengan rencana dapat memungkinkan siswa untuk memantau kemajuan belajarnya. Evaluasi dan monitoring diperlukan untuk mengetahui kesalahan. Kegiatan menarik kesimpulan dan rekapitulasi dapat menghasilkan penjelasan yang jelas bagi siswa.

Hasil penelitian menunjukkan adanya peningkatan kemampuan metakognitif siswa melalui penerapan model pembelajaran talking stick. Tim MKPBM (dalam Maulana,2008) memandang metakognitif sebagai suatu bentuk kemampuan untuk melihat pada diri sendiri sehingga apa yang siswa lakukan dapat terkontrol secara optimal. Para siswa dengan pengetahuan metakognitifnya sadar akan kelebihan dan keterbatasannya dalam belajar. Artinya saat siswa mengetahui kesalahannya, mereka sadar untuk mengakui bahwa mereka salah, dan berusaha untuk memperbaikinya.
Model pembelajaran talking stick membantu siswa dalam membaca dan memahami materi secara singkat karena kerbatasan waktu yang ditentukan. Karami dan Hashemian (2012) menyatakan bahwa penggunaan strategi metakognitif sangat mempengaruhi dalam pemahaman membaca siswa. Siswa sebagai subyek penelitian lebih unggul dibandngkan peserta didik yang tidak diterapkan strategi metakognitif. Model pembelajaran talking stick memberi kesempatan kepada siswa untuk berfikir secara mandiri, melatih siswa menjawab pertanyaan, sehingga kondisi kelas menjadi lebih baik dan siswa lebih siap Putri (2010).

Aspek aktivitas belajar siswa pada Siklus I sebesar 40,3\%, aktivitas belajar siswa pada siklus I menunjukkan siswa cukup aktif, hal ini terlihat pada banyaknya siswa yang tidak memperhatikan penjelasan guru dan memilih untuk mengobrol dengan teman sebangku. Aktivitas belajar siswa pada siklus II mengalami peningkatan menjadi $82,62 \%$. Aspek tertinggi yang dicapai pada ranah aktivitas belajar siswa adalah memperhatikan apa yang disampaikan guru, bekerjasama dengan teman dan memiliki kepedulian terhadap kesulitan sesama teman.

Widodo dan Lusi (2013: 1) untuk memperoleh hasil belajar berupa perpaduan antara aspek kognitif, afektif, dan psikomotor secara proposional. Keaktifan siswa ada yang secara langsung dapat diamati dan ada yang tidak dapat diamamti secara langsung, seperti mengerjakan tugas, berdiskusi, dan mengumpulkan data. Kadar keaktifan siswa tidak hanya ditentukan oleh aktivitas fisik semata, tetapi juga oleh aktivitas nonfisik seperti mental, intelektual, dan emosional, oleh sebab itu, aktif atau tidaknya siswa dalam belajar hanya siswa sendiri yang mengetahui secara pasti. Menurut Melati (2011) peningkatan aktivitas dapat diketahui dari semakin banyaknya jumlah siswa yang aktif dalam proses pembelajaran. Hasil penelitian menunjukkan adanya peningkatan aktivitas 
belajar siswa melalui penerapan model pembelajaran talking stick.

Data observasi kualitas pembelajaran dari observer menunjukan bahwa guru dan siswa telah melaksanakan kegiatan pembelajaran dengan baik. Siklus 1 bimbingan guru terhadap siswa dalam proses belajar mengajar kurang. Hal tersebut diperbaiki pada siklus selanjutnya. Siklus 2 bimbingan guru yang diberikan dalam sudah baik karena sudah terbiasa memberikan bimbingan kepada siswa. Hasil kualitas pelaksanaan pembelajaran untuk siklus $1 \mathrm{ke}$ siklus 2 mengalami peningkatan dari 2,25 menjadi 4,5 dengan kriteria "baik". Kriteria baik diperoleh dari observer yang menunjukan bahwa kualitas pelaksanaan pembelajaran dengan penggunaan model talking stick memiliki kualitas yang baik untuk dapat meningkatkan kemampuan metakognitif dan aktivitas belajar siswa kelas VII SMPN 1 Balerejo.

\section{SIMPULAN}

Berdasarkan hasil penelitian dapat disimpulkan bahwa penerapan model pembelajaran talking stick dapat meningkatkan kemampuan metakognitif dalam hal perencanaan, tindakan, monitoring, dan evaluasi. Hasil nilai pada siklus I sebesar 44,22 meningkat menjadi 84,74 pada siklus II. Aktivitas belajar siswa meningkat dalam hal menyampaikan pendapat, bekerjasama dengan teman, bertanggung jawab dalam tugas, bertukar pendapat, perencanaan, menyimpulkan materi pelajaran, dan mengerjakan kuis. Hasil nilai pada siklus I sebesar 40,3 meningkat menjadi 82,625 pada siklus II di SMPN 1 Balerejo Pada Materi Pelajaran Kepadatan Populasi Terhadap Lingkungan. Diperlukan pelaksanaan penelitian sejenis dengan memperhatikan saran untuk mengetahui efektivitas model pembelajaran talking stick dalam meningkatkan metakognisi dan aktivitas belajar. Sebaiknya peneliti lebih teliti dalam memilih instrumen agar tepat dalam pengukuran.

\section{DAFTAR PUSTAKA}

Karami, Somayeh dan Hashemian, M. (2012). The Relationship Between (Metacognitive) Strategi and reading comprehension in Iranian Female L2 Learners. International journal of English Linguistics (Online). (4), Hal 5, (http://www.ccsenet.org/journal/in dex.php) diunduh 7 juli 2015.

Ma'rifah, Siti. (2013). Peningkatan Aktivitas Dan Hasil Belajar Siswa Melalui Model Pembelajaran Problem Based Learning (Pbl) ( Studi Pada Kelas X Bisnis Dan Manajemen Mata Pelajaran Kewirausahaan Di Smk Ardjuna 1 Malang). Artikel Penelitian. Fakultas Sains dan Teknologi Universitas Islam Negeri Sunan Kalijaga Yogyakarta.

Marheny L., Herawati S., Ibrohim dan Duran C. (2014). Lesson Study In Improving The Role Of E-Portfolio On The Metacognitive Skill And Concept Comprehension: A Study On Cell Biology Subject In Ikip Pgri Madiun, Indonesia. American Journal of Educational Research. Vol 2, (10).

Maulana. (2008). Pendekatan Metakognitif Sebagai Alternatif Pembelajaran Matematika Untuk Meningkatkan Kemampuan Berpikir Kritis Mahasiswa PGSD. Jurnal Pendidikan Dasar. (10), Hal 4, diunduh 7 Juli 2015.

Melati. (201)1. Meningkatkan Aktivitas Dan Hasil Belajar Siswa Sman 1 Sungai Ambawang Melalui Pembelajaran Model Advance Organizer Berlatar Numbered Heads Together (NHT) Pada Materi Kelarutan Dan Hasil Kali Kelarutan. Jurnal Visi Ilmu Pendidikan (Online). Jilid 6, (1), Hal 10 , 
http://jurnal.untan.ac.id/index.php. diunduh 7 Juli 2015.

Mumpuni, Elok. (2012). Pengaruh Strategi Pembelajaran Instad Terhadap Metakognisi Dan Hasil Belajar Kognitif Biologi Siswa Sma Batik 1 Surakarta Tahun Pelajaran 2011/2012. Artikel Penelitian. Fakultas Keguruan Dan Ilmu Pendidikan Universitas Sebelas Maret Surakarta.

Putri, Abrianti. (2010). Penggunaan Model Pembelajaran Talking Stick dalam Meningkatkan Hasil Belajar PKn bagi Siswa Kelas VII-D di SMP Negeri 19 Malang. Malang.

Veenman, JVM., Wilhelm, P., dan Beishuizen, J. (2004). The Relation Between Intellectual and Metacognitive Skills from a Developmental perspective. Jurnal
Learning and Intruction. Jilid 14, (1), Hal 2, di unduh 20 juni 2015.

Widodo dan Lusi W. (2013). Peningkatan Aktivitas Belajar Dan Hasil Belajar Siswa Dengan Metode Problem Based Learning Pada Siswa Kelas Viia Mts Negeri Donomulyo Kulon Progo Tahun Pelajaran 2012/2013. Jurnal Fisika Indonesia (Online). Hal 1, diunduh 8 Juli 2015.

Wulandari, Erma. (2012). Penerapan Model Cooperative Learning Tipe Student Teams Achievement Division (Stad) Berbantu Media Monopoli Dalam Peningkatan Aktivitas Belajar Akuntansi Siswa Kelas X Akuntansi 2 Smk Negeri 1 Godean Tahun Ajaran 2011/2012. Jurnal Pendidikan Akuntansi Indonesia (Online), X, hal 144-145, diunduh 13 Maret 2015. 